RAD Conference Proceedings, vol. 2, pp. 137-140, 2017

www.rad-proceedings.org

\title{
OUTDOOR AND INDOOR AMBIENT DOSE EQUIVALENT RATES IN BERANE TOWN, MONTENEGRO
}

\author{
Ljiljana Gulan' ${ }^{*}$, Lidija Spasović ${ }^{2}$ \\ ${ }^{1}$ University of Priština, Faculty of Natural Sciences and Mathematics, Kosovska Mitrovica, Serbia \\ ${ }^{2}$ Primary School "Radomir Mitrović", Berane, Montenegro
}

\begin{abstract}
This paper presents the results of ambient dose rate measurements conducted in the air of Berane town, Republic of Montenegro. Measurements were performed by Geiger-Müller counter - Radex RD15O3 ${ }^{+}$, in the middle of October 2015. An average daily value of $114.8 \mathrm{nSv} / \mathrm{h}$ of ambient dose equivalent rate was obtained, spanning from $50-160 \mathrm{nSv} / \mathrm{h}$ in the morning and $70-177 \mathrm{nSv} / \mathrm{h}$ in the evening. Analysis of the impact of spatial variations on gamma radiation levels shows a very weak correlation between indoor ambient dose rate and outdoor ambient dose rate measured either in the morning $(r=0.09)$ or in the evening $(r=0.19)$. Building materials or stuff in buildings do not contribute additionally to ambient dose rates. Due to the lack of published data of dose rates, these results are the first measurements of radiation levels in Berane town.
\end{abstract}

Key words: Ambient dose equivalent rate, correlation, indoor, measurement, outdoor

DOI: $10.21175 / \operatorname{RadProc} .2017 .28$

\section{INTRODUCTION}

Natural radiation in the environment constantly and unavoidably comes from terrestrial radionuclides in rocks and minerals of the Earth's crust and cosmic radiation, as well as continuous production of cosmogenic radionuclides from cosmic space and atmosphere [1]. An important component of natural radiation is terrestrial radiation of ${ }^{\circ} \mathrm{K}$ and radionuclides from ${ }^{238} \mathrm{U}$ and ${ }^{232} \mathrm{Th}$ series. The main characteristic of these radionuclides is a long half-life, comparable to the age of the Earth. Another component of natural radiation is cosmic radiation that consists of charged particles of very high energies. It rarely reaches the Earth's surface, since it disappears in the interactions with the atmosphere and creates secondary radiation. In the interaction of a cosmic ray with the nuclei of hydrogen, nitrogen, argon, oxygen and other atoms in the atmosphere, cosmogenic radionuclides are produced. The most important are ${ }^{3} \mathrm{H},{ }^{7} \mathrm{Be},{ }^{14} \mathrm{C}$ and ${ }^{22} \mathrm{Na}$, yielding the average individual annual effective dose of $0.01 \mu \mathrm{Sv}, 0.03 \mu \mathrm{Sv}, 12 \mu \mathrm{Sv}$ and $0.15 \mu \mathrm{Sv}$, respectively [1].

More than 2/3 of the total annual dose received by the population comes from natural sources of radiation [1]. Worldwide average value of annual dose from natural sources is estimated to be $2.4 \mathrm{mSv}$, of which the inhalation of natural radioactive gas radon contributes $52 \%$, external terrestrial radiation $20 \%$ and cosmic \& cosmogenic radiation $16 \%$. Ingestion of $40 \mathrm{~K}$ and radionuclides from ${ }^{238} \mathrm{U}$ and ${ }^{232} \mathrm{Th}$ series amounts the remaining 12\%. According to the recommendations of international organizations [2-4], the lower value of the typical range of the total average worldwide exposure to natural radiation sources is $1 \mathrm{mSv} / \mathrm{y}$. The typical range for total cosmic and cosmogenic sources is $0.3^{-}$ $1.0 \mathrm{mSv} / \mathrm{y}$, while $0.3-0.6 \mathrm{mSv} / \mathrm{y}$ is the typical range for total external terrestrial sources which depend on radionuclide content in soil and building materials [1].

There are areas in the world with high natural radiation background (in Brazil, USA, China, India) due to the elevated content of radionuclides in the soil or rocks, intensity of cosmic radiation, geographical location, etc. [5]. Basic radiation, which is registered in normal conditions, comes from cosmic radiation and natural radionuclides, and depends on the geology of the terrain, an altitude of measuring point, and it is characteristic of a certain location.

In addition to natural sources of radiation, as a result of human activity, the artificial sources of ionizing radiation are also present in the environment. After World War II, some fission products, such as ${ }^{137 \mathrm{Cs}}$ and ${ }^{\circ} \mathrm{Sr}$, appeared in the environment as a consequence of nuclear technologies used for military and peaceful purposes.

The variation of terrestrial gamma radiation is usually greater than the variation of cosmic radiation. Higher radiation levels are associated with igneous rocks (granite), and lower levels with sedimentary rocks [1]. Therefore, it is important and desirable to measure the gamma absorbed dose rate or ambient dose equivalent rate everywhere in human environment, where it is possible. Since no

*ljiljana.gulan@pr.ac.rs 
documented data exist about radioactivity in town Berane, the aim of this work was to point out the preliminary results of radiation levels, i.e. background radiation.

\section{EXPERIMENTAL}

\subsection{Geology of the studied area}

In terms of physical geography, Berane municipality is very diverse with complex processes in the geological past from the Tertiary period which influenced the formation of primary ore (lead and zinc), pedological and hydrological characteristics. The Berane basin represents a tectonic-erosive enlargement incorporated into the Police, Krčevo and other surfaces. The composition of Berane basin involves mainly Paleozoic sediments, Triassic limestones and Neogene sediments. Bjelasica massif is composed of Paleozoic shales (sandstones, phyllite). On the opposite side, Cmiljevica is made up mainly of Triassic limestone, with pad of shales and cherts. Neogene sediments (clay and marlstone) cover a large expanse on the right side of Lim, hill Jasikovac, a part of Budimlje, and most of the Police surface. It is mainly found in groundwater sources. While the right side of the basin is represented by Neogene undulating relief, the left side has three fluvial-glacial (gravel, sand) terraces [6].

Temperature relations and winds correspond to moderate-continental types, whereas the rainfall corresponds to Mediterranean climate effects. The average annual rainfall is $923.2 \mathrm{~mm}$ [6].

The municipality of Berane $\left(42^{\circ} 50^{\prime} \mathrm{N}-19^{\circ} 52^{\prime} \mathrm{E}\right)$ is located in North-Eastern part of Montenegro and covers an area of $647 \mathrm{~km}^{2}$. Berane municipality had a population of 33,970, according to the census of 2011 . Berane town itself has 11,073 citizens [7].

\subsection{Method of measurements}

Indoor and outdoor dose rate measurements were conducted in the middle of October 2015 in Berane town. The measurements were performed at the height of $1 \mathrm{~m}$ above ground, outdoor in the morning and in the evening of the same day, and indoor in nearby buildings; indoor measurements were conducted in the evening. Four measurements were made at one measuring point. For all locations, elevations and the ages of the building construction were noted. There was no rainfall on the day the measurements were done, and on the preceding 2 days. The map of Berane town with seventeen measuring points is presented in Fig.1.

The measurement was performed by GeigerMüller counter, Radex $\mathrm{RD}_{1503^{+}}$. Radex model $\mathrm{RD}_{1503}{ }^{+}$operates on a temperature range from -18 ${ }^{\circ} \mathrm{C}$ to $+65{ }^{\circ} \mathrm{C}$. The measuring cycle is 40 seconds for the ambient gamma dose rates in the range from 0.05 to $9.99 \mu \mathrm{Sv} / \mathrm{h}$ [8]. The measurement uncertainty of the unit for gamma rays is $\pm 15 \%$ [8]. Due to low detector's response, detection of high-energy particles from cosmic radiation was negligible.

Instruments for gamma dose rate measurements are calibrated and based on an ambient dose equivalent from which the dose estimation is possible. 138
Ambient dose equivalent $\mathrm{H}^{*}(10)$ at a point of the radiation field is the dose equivalent that would be produced by the corresponding expanded and aligned field at a depth of $10 \mathrm{~mm}$ in the ICRU sphere, on the radius opposing the direction of the aligned field (for penetrating gamma radiation) [2].

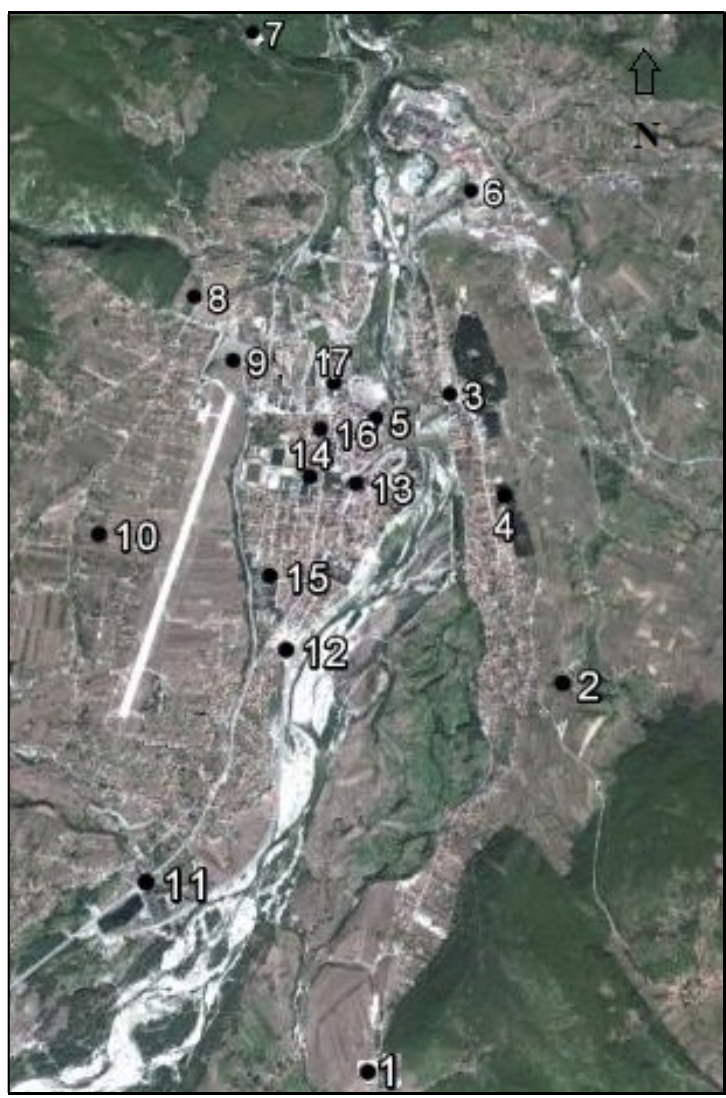

Figure 1. Map of Berane town with locations of ambient dose rate measurements

\section{RESULTS AND DISCUSSION}

Ambient dose equivalent rates were measured at 17 different locations in the town of Berane marked on Fig. 1. The results of the indoor and outdoor ambient dose equivalent rate measurements are presented in Table 1. Since, the use of Radex monitor is limited for high cosmic ray measurement, the dose rate of natural radiation known as a terrestrial type of radiation, as well as radionuclides in the air (radon progenies, ${ }^{7} \mathrm{Be}$ and ${ }^{22} \mathrm{Na}$ in the atmosphere) were measured." Assuming that average outdoor radon concentration of $10 \mathrm{~Bq} / \mathrm{m}^{3}$ would contribute about $2.5 \mathrm{nSv} / \mathrm{h}$, and contributions from gamma radiating ${ }^{7} \mathrm{Be}$ and ${ }^{22} \mathrm{Na}$ are far below $1 \mathrm{nSv} / \mathrm{h}$ [9], the total contribution of this component to the dose rate is very small.

In addition, dose rates in air were changed from place to place and also with time, assuming that diversity of the soil composition affects more variations on total dose rates than cosmic radiation. Also, meteorological conditions, micro relief and vegetation of ground could influence the variation of measured dose rate [9]. 
A descriptive statistic of dose rate measurements is given in Table 2. The dose rates varied in the range of $50-160 \mathrm{nSv} / \mathrm{h}$ with an average value of $112.4 \mathrm{nSv} / \mathrm{h}$ in the morning; the average value in the evening was 117.1 $\mathrm{nSv} / \mathrm{h}$ (70-177 $\mathrm{nSv} / \mathrm{h})$; the average daily dose rate in Berane is calculated to be $114.8 \mathrm{nSv} / \mathrm{h}$. The maximum values were measured outdoors in hospital surroundings (location no. 17, Fig.1). The KolmogorovSmirnov test of normality shows normal distribution of both, outdoor and indoor data set results (this is also evident from Table 2, as low value of skewness); and the median around the mean values.

Dose rates measured in nearby buildings varied from 90 to $167 \mathrm{nSv} / \mathrm{h}$, with an average value of 128.1 $\mathrm{nSv} / \mathrm{h}$. There was no significant difference between measured dose rates concerning the elevations or the age of building construction.

Since the Report of population exposure to ionizing radiation in the Republic of Montenegro is not available, a comparison with the results of ambient dose equivalent rates is not possible. According to data from Serbian Radiation Protection and Nuclear Safety Agency, the average value of $114.8 \mathrm{nSv} / \mathrm{h}$ of ambient dose equivalent rate is comparable with the values in other towns in Serbia (e.g. Zlatibor, Novi Sad) [10].

Table 1. Outdoor and indoor ambient dose equivalent rate measurements in Berane town

\begin{tabular}{|c|c|c|c|}
\hline \multirow{3}{*}{$\begin{array}{l}\text { Location } \\
\text { number }\end{array}$} & \multicolumn{3}{|c|}{ Ambient dose equivalent rate $(\mathrm{nSv} / \mathrm{h})$} \\
\hline & \multicolumn{2}{|c|}{ Outdoor } & Indoor \\
\hline & Morning & Evening & Building \\
\hline 1. & 50 & 85 & 130 \\
\hline 2. & 135 & 147 & 155 \\
\hline 3 . & 105 & 142 & 152 \\
\hline 4. & 102 & 97 & 155 \\
\hline 5 . & 152 & 82 & 167 \\
\hline 6. & 120 & 107 & 127 \\
\hline 7. & 122 & 110 & 142 \\
\hline 8. & 90 & 137 & 92 \\
\hline 9. & 135 & 127 & 115 \\
\hline 10. & 140 & 160 & 147 \\
\hline 11. & 117 & 130 & 110 \\
\hline 12. & 90 & 100 & 110 \\
\hline 13. & 115 & 70 & 110 \\
\hline 14. & 85 & 75 & 145 \\
\hline 15. & 107 & 115 & 90 \\
\hline 16. & 85 & 130 & 135 \\
\hline 17. & 160 & 177 & 95 \\
\hline
\end{tabular}

Table 2. Descriptive statistics of ambient dose equivalent rate measurements in Berane town

\begin{tabular}{|c|c|c|c|}
\hline \multirow[t]{3}{*}{ Parameter } & \multicolumn{3}{|c|}{$\begin{array}{l}\text { Ambient dose equivalent rate } \\
\qquad(\mathrm{nSv} / \mathrm{h})\end{array}$} \\
\hline & \multicolumn{2}{|c|}{ Outdoor } & Indoor \\
\hline & Morning & Evening & Building \\
\hline Minimum & 50 & 70 & 90 \\
\hline Maximum & 160 & 177 & 167 \\
\hline Mean & 112.4 & 117.1 & 128.1 \\
\hline Median & 115 & 115 & 130 \\
\hline $\mathrm{SD}^{*}$ & 27.8 & 30.5 & $24 \cdot 3$ \\
\hline Geomean & 108.7 & $113 \cdot 3$ & 125.8 \\
\hline Skewness & -0.30 & 0.20 & -0.16 \\
\hline Kurtosis & 0.22 & -0.65 & -1.23 \\
\hline
\end{tabular}

* SD-Standard Deviation
The annual average effective dose for the population of Berane town is calculated to be $0.2 \mathrm{mSv}$ using the 0.2 occupancy factors for exposure outdoors; similarly, for exposure indoors, the annual average effective dose is estimated to be $0.9 \mathrm{mSv}$ (0.8 occupancy factor is assumed). In fact, annual effective doses will be lower than the $0.2 \mathrm{mSv}$ and $0.9 \mathrm{mSv}$. This is because the ambient dose equivalent rate $\left(H^{*}(10)\right)$ is a conservative estimate for effective dose $E$ for the decay gamma rays. The relevant figure is Fig. 64 of ICRP 74 [11]. The $H^{*}(10)$ to effective dose conversion depends on the gamma ray energy spectrum and irradiation geometry. However, in the idealized case of ${ }^{40} \mathrm{~K},{ }^{232} \mathrm{Th}$ and ${ }^{238} \mathrm{U}$ uniformly distributed in the soil, the effective dose is about $60 \%$ of $\mathrm{H}^{*}(10)$, meaning $0.2->0.12 \mathrm{mSv} / \mathrm{y}$ and $0.9->0.54 \mathrm{mSv} / \mathrm{y}$. This means that the total effective dose for Berane (0.66 mSv/y), in reality, is closer to the worldwide average of $0.48 \mathrm{mSv} / \mathrm{y}$ for terrestrial radiation.

Correlation analysis of the impact of spatial variations on ambient dose equivalent rates shows that a very weak correlation exists between the indoor and outdoor dose rates: Pearson's coefficients are $r=0.09$ (in the morning) and $\mathrm{r}=0.19$ (in the evening). Correlation between outdoor dose rate measurements is presented in Fig. 2; correlation coefficient between them is 0.45 .

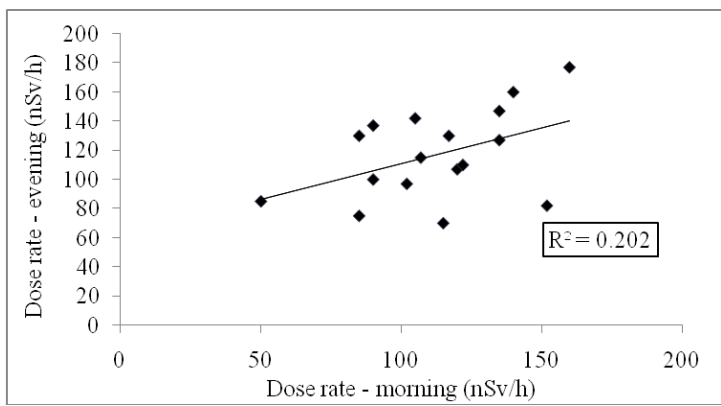

Figure 2. Correlation between outdoor dose rate measurements (morning/evening)

The Mann-Whitney Test showed there were no significant differences in values between the outdoor and indoor gamma dose rates at a significant level of $\mathrm{p}<0.01$. Since there are no major differences in values between the outdoor and indoor gamma dose rates, one can conclude that buildings did not contain a high percentage of ${ }^{4} \mathrm{~K},{ }^{232} \mathrm{Th}$ and ${ }^{238} \mathrm{U}$ and progeny, which would additionally contribute to the ambient dose rate. For most measurements, the difference between indoor and outdoor measured values was up to $30 \mathrm{nSv} / \mathrm{h}$ [12]. If the indoor dose rate differs from the outdoor dose rate in the range of $100-200 \mathrm{nSv} / \mathrm{h}$, than we can assume an increase of the specific activity of natural radionuclides regarding building materials [13].

\section{CONCLUSION}

First measurements of outdoor and indoor ambient dose equivalent rates in Berane town were presented in this paper. The obtained results showed an average outdoor dose rate of $115 \mathrm{nSv} / \mathrm{h}$, without relevant difference in the time of day when measurements were done. The average dose rate measured inside nearby 
buildings was $128 \mathrm{nSv} / \mathrm{h}$. Therefore, we conclude that any material used for selected building construction (some of them were embedded in several centuries before) does not contribute additionally to ambient dose rate.

Acknowledgement: The paper is a part of the research done within the project no. III 41028 supported by the Ministry of Education, Science and Technology Development of the Republic of Serbia.

\section{REFERENCES}

1. "UNSCEAR 2000 Report: Sources and effects of ionizing radiation," UNSCR, New York, (NY), USA, Rep. 200o(vol. 1), 2000. Retrieved from: http://www.unscear.org/docs/publications/2000/UNS CEAR 2000 Report Vol.I.pdf Retrieved on: Jan. 12, 2017

2. "UNSCEAR 1993 Report: Sources and effects of ionizing radiation," UNSCR, New York, (NY), USA, Rep. 1993, 1993.

Retrieved from: http://www.unscear.org/docs/publications/1993/UNS CEAR 1993_Report.pdf Retrieved on: Jan. 12, 2017

3. The 2007 Recommendations of the International Commission on Radiological Protection, 1st ed., ICRP, Ottawa, Canada, 2007, pp. 247-322.

Retrieved from:

https://edisciplinas.usp.br/pluginfile.php/2353.51/mod resource/content/1/ICRP 103 todo.pdf

Retrieved on: Jan. 19, 2017

4. Depleted uranium: Sources, exposures and health effects, 1st ed., Dpt. of protection of the Human Environment of WHO, Geneva, Switzerland, 2001. Retrieved from: http://apps.who.int/iris/bitstream/10665/66930/1/W HO SDE PHE 01.1.pdf

Retrieved on: Jan. 19, 2017.

5. "UNSCEAR 2008 Report: Sources and effects of ionizing radiation, Annex B - Exposures of the public and workers from various sources of radiation," UNSCR, New York, (NY), USA, Rep. 2008(vol. 1), 2008.

Retrieved from:

http://www.unscear.org/docs/reports/2008/o9-

86753_Report 2008 Annex B.pdf

Retrieved on: Jan. 17, 2017
6. Општина Беране, Википедија - слободна енциклопедија, Сан Франциско, САД. (Municipality of Berane, Wikipedia the free encyclopedia, San Francisko, (CA), USA.)

Retrieved from:

https://sr.wikipedia.org/sr/Општина Беране

Retrieved on: Sep. 05, 2016

7. М. Лутовац, Иванградска (Беранска) котлина: Регионално-географска испитивања, Београд, СФРЈ: Географски институт САН, 1957. (M. Lutovac, Ivangrad (Berane) basin: Regional geographic examinations, Belgrade, SFRY: Institute of Geography SAS, 1957.)

8. Radiation Detector RADEX RD15O3+, Quarta-Rad, Moscow, Russia. Retrieved from:

https://www.quarta-rad.ru/en/catalog/dozimetrradiometr-radon/dozimetr-radex-rd1503/ Retrieved on: Apr. 26, 2017

9. P. Bossew, G. Cinelli, M. Hernandez-Ceballos et al., "Estimating the terrestrial gamma dose rate by decomposition of the ambient dose equivalent rate," Journal of Environmental Radioactivity, vol. 166, pp. 296-308, Jan. 2017.

DOI: 10.1016/j.jenvrad.2016.02.013

PMid: 26926960

10. "Извештај о излагању становништва јонизујућем зрачењу у 2015. год," Агенција за заштиту од јонизујућих зрачења и нуклеарну сигурност Србије, Београд, Србија, 2016. (“Annual Report of population exposure to ionizing radiation in 2015," Serbian Radiation Protection and Nuclear Safety Agency, Belgrade, Serbia, 2016.)

Retrieved from:

http://www.srbatom.gov.rs/srbatom/doc/Izvestaj\%20 Monitoring\%202015.pdf

Retrieved on: Jan. 13, 2017

11. Conversion Coefficients for use in Radiological Protection against External Radiation, 1st ed., ICRP Ottawa, Canada, 1996.

12. Lj. Gulan, Z. S. Zunic, G. Milic, T. Ishikawa, Y. Omori, B. Vuckovic, D. Nikezic, D. Krstic, P. Bossew, "First step of indoor thoron mapping of Kosovo and Metohija" Radiat. Prot. Dosimetry, vol. 162, no. 1-2, pp. 157-162, Nov. 2014.

DOI: $10.1093 / \mathrm{rpd} / \mathrm{ncu} 250$

PMid: 25080438

13. М. В. Жуковский, В. Б. Гурвич, И. В. Ярмошенко, Радоновая безопасность зданий, Екатеринбург, Россия: УрО РАH, 2000. (М. V. Zhukovsky, V. B. Gurvich, I. V. Yarmoshenko, Radon Building Safety, Yekaterinburg, Russia: UB RAS, 200o.) 